\title{
Butyrophilins: an important new element of resistance
}

\author{
MAGDALENA MALINOWSKA, BEATA TOKARZ-DEPTUŁA, WIESEAW DEPTUŁA
}

Szczecin University, Szczecin, Poland

\begin{abstract}
Butyrophilins belonging to the immunoglobulin superfamily are new immune system regulators because they are present on lymphocytes, dendritic cells, monocytes, macrophages, neutrophils and eosinophils, and they exert a stimulatory and (or) inhibitory effect on them. The role of butyrophilins is associated and results from their similarity to the regulatory $B 7$ protein family involved in the modulation of immune phenomena. Butyrophilins are glycoproteins built of two extracellular immunoglobulin domains, stabilized with disulfide bonds: constant IgC, and variable IgV and a transmembrane region. Most of these proteins contain a conserved domain encoded by a single exon-B30.2, also referred to as PRYSPRY. In humans, the family of butyrophilins includes 7 butyrophilin proteins, 5 butyrophilin-like proteins and the SKINT-like factor. Butyrophilins have been also demonstrated to play a role in various infections, e.g. tuberculosis or diseases that include sarcoidosis, systemic lupus erythematosus, rheumatoid arthritis, genetic metabolic diseases, ulcerative colitis, cancer and kidney disease.
\end{abstract}

Key words: butyrophilins, butyrophilin-like protein, immune system.

(Centr Eur J Immunol 2017; 42 (4): 399-403)

\section{Introduction}

Infections, autoimmune diseases or cancers can stimulate or inhibit an immune response, thus studies on these issues focus on understanding the molecular basis of T-cell reactivity, including their activation, which has been linked to two independent signals, i.e., TCR receptor present on the surface of T-cells (signal I) and co-stimulatory molecules, expressed abundantly on antigen-presenting cells (APC) (signal II) [1, 2]. These important elements regulating T-cell responses are some of the immunomodulatory molecules best described so far - proteins of the B7 family [3], which stimulate the immune response of T lymphocytes, e.g. B7.1 (CD80), B7.2 (CD86) and ICOS (inducible T-cell co-stimulator) molecules [4] as well as suppressing molecules, such as PDL-1 (PD1 ligand), PDL-2 (PD2 ligand), B7-H3 (B7 homolog 3) or B7-H4 (B7 homolog 4) [5-8]. Butyrophilins are a recently discovered large family of proteins within the members of the immunoglobulin superfamily which are analogous in this respect to the B7 protein family [9].

\section{Structure and classification of butyrophilins}

The first butyrophilins were described in the 1980s as proteins present in epithelial cells of the mammary gland, which are involved in lactation - particularly in the secre- tion, formation and stabilization of fat balls in cow's milk [10]. Butyrophilins, similarly as the B7 family of regulatory proteins, are glycoproteins built of two extracellular immunoglobulin domains, stabilized with disulfide bonds: constant $\mathrm{IgC}$, and variable $\mathrm{IgV}$ and a transmembrane region (Fig. 1).

In addition, most butyrophilins contain a conserved domain encoded by a single exon - B30.2, also referred to as PRYSPRY [4]. Among butyrophilins (BTN), three subfamilies BTN1A, BTN2A and BTN3A have an identical structure, although the BTN3A2 protein has no B30.2 domain [3, 4, 9, 11-13]. Butyrophilin-like proteins also have a conventional structure composed of two immunoglobulin domains and the B30.2 domain [3, 4, 9, 11-13]. In turn, SKINT proteins have three transmembrane regions, however, they do not contain the B30.2 domain [4], and some of them are additionally lacking one of the immunoglobulin domains - $\operatorname{IgV}$ or $\operatorname{IgC}[12]$.

In humans, the family of butyrophilins includes 7 butyrophilin proteins (BTN1A1, BTN2A1, BTN2A2, BTN2A3, BTN3A1, BTN3A2, BTN3A3), 5 butyrophilin-like proteins (BTNL) (BTNL2, BTNL3, BTNL8, BTNL9, BTNL10) and the SKINT-like factor (SKINTL - selection and upkeep of intraepithelial T-cells) [9, 11, 14], while in mice, 11 proteins of this family have been described: BTN1A1, BTN2A2, BTNL1, BTNL2, BTLN4, BTNL5, BTNL6, BTNL7, BTNL9, BTNL10 and SKINTL, which differ in

Correspondence: Beata Tokarz-Deptuła, Szczecin University, Felczaka 3c, Szczecin, Poland, e-mail: kuki001@interia.pl Submitted: 7.02.2017; Accepted: 13.03.2017 


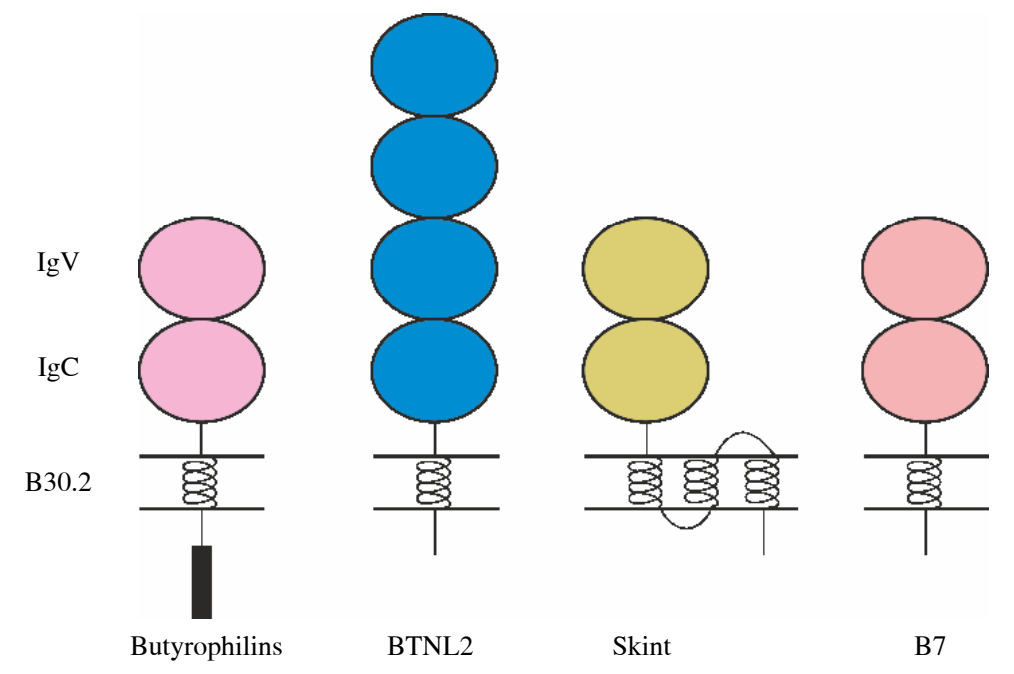

Fig. 1. Structural organization of butyrophilins and B7 family

humans and mice [13]. It was shown that seven human butyrophilin genes are arranged in three phylogenetic groups, i.e., BTN1, BTN2 and BTN3, which are located on the short arm of chromosome 6 (6p22.1) in the region of MHC class I molecules, and they determine three butyrophilin subfamilies mentioned above (BTN1, BTN2 and BTN3) [11, 14]. It was demonstrated that the BTN1 subfamily is encoded by a single gene: BTN1A1, while BTN2 (BTN2A1, BTN2A2, BTN2A3) and BTN3 (BTN3A1, BTN3A2, BTN3A3) subfamilies have three genes each $[4,11]$. The proteins of these three subfamilies, i.e., BTN1, BTN2 and BTN3 show a high homology of amino acid residues reaching up to $50 \%$, even though this homology between BTN2 and BTN3 subfamily is sometimes more than $80 \%[14,15]$. Similarly as genes coding for butyrophilins, the genes of butyrophilin-like proteins are grouped in three clusters, namely: BTNL3, BTNL8 and BTNL9, which in humans are located on the long arm of chromosome 5 (5q35) [4]. SKINT proteins belonging to the family of butyrophilins [16] are determined in humans by three groups of genes, i.e., Skint 1-6, Skint 7/8 and Skint 9-11 [12]. It has also been proven that mRNAs encoding BTN and BTNL proteins are present in T and B lymphocytes, neutrophils, eosinophils as well as on the bone marrow, brain, lung, liver, small intestine and colon cells [3, 11].

\section{Butyrophilins, cells of the immune system and infections, and pathological states}

Butyrophilin importance in the body is associated with their stimulatory and inhibitory effects on cells of the immune system. An example can be the BTN2A1 butyrophilin, which is one of the few among these proteins that binds to DC-SIGN - pectin type C receptor (DC-specific
ICAM3-grabbing non-integrin, also referred to as CD209), which is present on monocytes and dendritic cells and acts as an internalization receptor of HIV-1, HCV, but also other pathogens [15]. It was described that BTN1A1, BTN2A2, BTNL2 proteins of the butyrophilin family exerted an inhibitory effect on the proliferation of CD4+ $\mathrm{T}$-cells through the cell cycle arrest and suppressed the proliferating activity of CD8+ T-cells [17-19]. These proteins also reduce the expression of a variety of cytokines associated with T-cell activation, including IL-2 and IFN- $\gamma$ [20]. Stefferl et al. [21] demonstrated that the administration of recombinant BTN1A1 reduced T-cell activation, thereby inhibiting the development of diseases, such as experimental autoimmune encephalomyelitis in rat models. These investigators [21] suggested that due to the similarity of this butyrophilin to myelin oligodendrocyte glycoprotein, it might also mediate the modulation of T lymphocyte activation. In turn, Swanson et al. [22] and Amman et al. [20], studying BTNL2 in vitro, demonstrated that this protein activated the expression of Foxp3 factor (forkhead box P3) - a key transcription factor involved in the regulation of immune response, which is responsible for the formation of regulatory T-cells. This protein also delays the signal from B7 proteins, as a result of decreased proliferation of T-cells, leading to the inhibition of proteins, such as IL-2, IL-13, IL-17 or IFN- $\gamma$ [22]. The BTNL2 butyrophilin also inhibits the Akt activity (serine-threonine protein kinases), and maintains the activity of FOXO1 factor (forkhead box protein O1), thereby increasing the expression of Foxp3 factor [22]. In the case of the BTN3A1 protein, it was demonstrated in humans that it inhibited T-cell proliferation and cytokine production by Th1 lymphocytes by blocking the level of the 
cFLIP controller (cellular FLICE (FADD-like IL-1 $\beta$-converting enzyme) inhibitory protein), which led to the silencing of caspase- 8 , which is required for the activation of NF- $\kappa \mathrm{B}$ transcription factor [23]. The BTN3A1 butyrophilin, known as CD277 receptor, is stabilized in the myeloid dendritic cells and macrophages by vascular endothelial growth factor (VEGF), and by the $\mathrm{CCl} 3$ (chemokine ligand 3) chemokine in ovarian cancer cells [23, 24]. The BTNL8 protein also plays an important role among butyrophilins, and it is expressed on neutrophils, T lymphocytes and myeloid lineage cells [25]. This butyrophilin, in the presence of the anti-CD3 protein, binds T-cells, and administered as BTNL8-Ig, increases mainly the proliferation of CD4+ and CD8+ T-cells, and enhances the synthesis of IFN- $\gamma$, TNF- $\alpha$, IL- 8 and IL-10 [25]. In turn, the BTN3A2 butyrophilin exhibits an immune co-stimulatory effect on immune processes in ovarian cancer in women, as the high mRNA level of that butyrophilin improves prognosis in epithelial ovarian cancer (EOC) [26]. It was also shown that the expression of this protein in ovarian cancer was positively correlated with intraepithelial infiltration of CD4+ and CD8+ T-cells [27], thus suggesting that it may be a good prognostic marker in EOC because it affects the modulation of immune cells, and hence it is involved in the immunity against this cancer [27].

Butyrophilins also affect $\mathrm{V} \gamma 9 \mathrm{~V} \delta 2 \mathrm{~T}$ lymphocytes - the main population of T-cells with the $\gamma \delta$ receptor in human blood, and these cells comprise 1-10\% of all T-cells in healthy individuals, in particular in the intestinal mucosa and mucosal tissues and liver [28-30]. These lymphocytes are characterized by a high reactivity of small organic pyrophosphate molecules [28] and show a strong reaction towards tumor cells [23] and pathogens, such as Plasmodium falciparum, Mycobacterium (M.) tuberculosis and M. leprae [31-34]. It was shown that during the biosynthesis of isoprenoids, e.g. HMBPP ((E)-4-hydroxy-3-methyl-but-2enyl, phosphate), which are produced via MEP (2-C-methyl-D-erytrtiol-4- phosphate) by Gram positive and Gram negative bacteria and pathogens and parasites, the detection of phosphoantigens occurred through BTN3A, which also activated $\mathrm{V} \gamma 9 \mathrm{~V} \delta 2$ T-cells [4, 28, 35-37]. Although it was not fully explained how this process occurred, two models explaining the interactions were proposed. The first model assumes that BTN3A, as a molecule that presents an antigen, captures and presents phosphoantigen on the surface of $\mathrm{V} \gamma 9 \mathrm{~V} \delta 2 \mathrm{~T}$-cells that recognize this complex directly by TCR [38]. The second model suggests that BTN3A1, as the only one of the three BTN3 isoforms is able to activate $\mathrm{V} \gamma 9 \mathrm{~V} \delta 2$ lymphocytes [39]. On the other hand, other authors [40] indicated that all three isoforms of this butyrophilin are required to activate these cells, and hence Sandstrom et al. [33] suggested that it was conditioned by the B30.2 domain present in butyrophilins, which "senses" the increased concentration of phosphoantigens so that it can serve as a "sensor" to detect changes in the level of isoprenoid metabolites [33].

Butyrophilins, in addition to the effects on T-cells, also affect other cells of the immune system. It was proven that BTN3A expressed on the surface of monocytes and dendritic cells caused their increased survival by the inhibition of apoptosis; they also increased the expression of molecules of this protein on these cells, thereby activating the synthesis of IL-1, IL-8 and IL-12 [41]. It was shown that the activation of monocytes and DC cells by the addition of BTN3A could also increase the immune signaling through TLRs (Toll-like receptors), which might suggest that the subfamily of these butyrophilins enhance proinflammatory signals [38]. In addition, it was suggested that BTN3A butyrophilins expressed on NK cells, but also BTN3A2 butyrophilins, contributed to the increased synthesis of IFN- $\gamma$ by these cells [42]. It was demonstrated that butyrophilins in the presence of IL-2 and IL-15 acted on local immune responses, including proliferation and IEL (intraepithelial lymphocyte) cell activity in the intestinal mucosa in mice [7]. In addition, it was reported that butyrophilin-like proteins regulated the expression of CD25 and caused increased secretion of IFN- $\gamma$ by IEL cells [7].

In addition to the involvement of butyrophilin family proteins in the experimental autoimmune encephalomyelitis [20] as well as genetic metabolic diseases, diabetes, and cancer [14], their role in infections (tuberculosis, leprosy, Plasmodium sp.) was also demonstrated [32-34]. The participation of butyrophilins was also described in sarcoidosis $[43,44]$ as well as in other conditions [43, 45-48]. In sarcoidosis it was shown that the mutant BTNL2 protein could not localize in the cell membrane and lost its inhibitory function, which led to abnormal activation of T-cells, and thereby to the inflammation in this disease. Their role was also described in humans [43] in the course of myositis, as during this disease an increased rate of BTNL2 butyrophilin mutation was observed [43]. A correlation was also demonstrated in humans between the BTNL2 polymorphism and ulcerative colitis [48], rheumatoid arthritis [47], systemic lupus erythematosus [46] and chronic renal diseases [46], which showed that this protein was involved in these pathological conditions. Despite the discussed examples of the participation and role of the BTNL2 butyrophilin in pathological states [46], observations in this field are still required to better elucidate the interaction between butyrophilins, including the BTNL2 polymorphism and various pathological conditions in mammals.

\section{Conclusions}

Butyrophilins, as a large family within the immunoglobulin superfamily, similarly as the B7 protein family, are present on many cells of the immune system and modulate their action. A picture of their effect both in terms of inhibiting and increasing the activity of these cells by 
these proteins, mainly T lymphocytes, indicates that there are new possible modulation pathways, and hence new interactions between the components of natural and acquired immunity in mammals both in physiological and pathological conditions.

\section{The authors declare no conflict of interest.}

\section{References}

1. Kusztal M, Jezior D, Weyda W, et al. (2007): Odpowiedź układu immunologicznego na aloprzeszczep nerki. Część I. Rola antygenów zgodności tkankowej, komórek prezentujących antygen i limfocytów w rozpoznawaniu aloantygenu: dwusygnałowa aktywacja limfocytu T. Postępy Hig Med Dosw 61: 13-20.

2. Rutkowski R, Moniuszko T (2001): Rola cząstek kostymulujących B7.1 (CD80) i B7.2 (CD86) w patomechanizmie odczynu zapalnego. Alergia Astma Immunol 6: 87-94.

3. Arnett HA, Escobar SS, Vibey JL (2009): Regulation of costimuation in the era ofbutyrophilins. Cytokine 46: 370-375.

4. Rhodes DA, Reith W, Trowsdale J (2016): Regulation of immunity by butyropfilins. Annu Rev Immunol 34: 151-172.

5. Grzywnowicz M, Giannopoulos K (2012): Receptor programowanej śmierci PD-1 oraz jego ligand PD-L1 jako potencjalne cele w terapii nowotworów. Acta Heamatol Pol 43: 132-145.

6. Kawasaki AY, Nishimura H, Ishida Y, et al. (1996): Expression of the PD-1 antigen on the surface of stimulated mouse T and B lymphocytes. Int Immunol 8: 765-772.

7. Lebrero-Fernandez C, Bergstrom JH, Pelasseyed T, Bas-Forsberg A (2016): Murine butyrophilin-like 1 and Btnl6 form heteromeric complexes in small instestinal ephitelial cells and promote proliferation of local T lymphocytes. Front Immunol 7: 1-13.

8. Sharpe AH, Freeman GJ (2002): The B7-CD28 superfamily. Nat Rev Immunol 2: 116-126.

9. Arnett HA, Viney JL (2014): Immune modulation by butyrophilins. Nature Immunol 14: 559-569.

10. Heid HW, Winter S, Bruder G, et al. (1983): Butyrophilin, an apical plasma membrane-associated glycoprotein characteristic of lactating mammary glands of diverse species. Biochim Biophys Acta 728: 228-238.

11. Abeler-Dörner L, Swamy M, Williams G, et al. (2012): Butyrophilins: an emerging family of immune regulators. Trends Immunol 33: 34-41.

12. Afrache H, Gouret P, Ainouche S, et al. (2012): The butyrophilin (BTN) gene family: from milk fat to the regulation of the immune response. Immunogenetics 64: 781-794.

13. Guo Y, Wang AY (2015): Novel immune check-point regulators in tolerance maintenance. Front Immunol 6: 421.

14. Niedźwiedzka-Rystwej P, Tokarz-Deptuła B, Deptuła W (2015): Koroniny i butyrofiliny - ważne białka układu odpornościowego. Post Biol Kom 42: 227-234.

15. Malcherek G, Mayr L, Roda-Navarro P, et al. (2007): The B7 homolog butyrophilin BTN2A1 is a novel ligand for DC-SIGN. J Immunol 179: 3804-3811.

16. Boyden LM, Lewis JM, Barbee SD, et al. (2008): Skint1, the protype of a newly identified immunoglobulin superfamily gene cluster, positively selects epidermal gammadelta $\mathrm{T}$ cells. Nat Genet 40: 656-666.
17. Nguyen T, Liu XK, Zhang Y, Dong C (2006): BTNL2, a butyrophilin-like molecule that functions to inhibit $\mathrm{T}$ cell activation. J Immunol 176: 7354-7360.

18. Smith IA, Knezevic BR, Amman JU, et al. (2010): BTN1A1, the mammary gland butyrophilin, and BTN2A3 are both inhibitors of T cell activation. J Immunol 184: 3514-3525.

19. Yamazaki T, Goya I, Graf D, et al. (2010): A butyrophilin family member critically inhibits T cell Activation. J Immunol 18: 5907-5914.

20. Ammann JA, Cooke A, Trwosdale J (2013): Butyrophilin Bt$\mathrm{n} 2 \mathrm{a} 2$ inhibits $\mathrm{T}$ cell receptors activation, PI3K/Akt pathway signaling, and induces Foxp3 expression I T lymphocytes. J Immunol 190: 5030-5036.

21. Stefferl A, Schubart A, Storch M, et al. (2000): Butyrophilin, a milk protein, modulates the encephalitogenic $\mathrm{T}$ cell response to myelin oligodendrocyte glycoprotein in experimental autoimmune encepgalomyelitis. J Immunol 165: 2859-2865.

22. Swanson RM, Gavin MA, Escobar SS, et al. (2013): Butyrophilin-like 2 modulates B7 costimulation to induce Foxp3 expression and regulatory $\mathrm{T}$ cell development in mature $\mathrm{T}$ cells. J Immunol 190: 2027-2035.

23. Gober HJ, Kistowska M, Angman L, et al. (2003): Human $\mathrm{T}$ cell receptor gammadelta cells recognize endogenous mevalonate metabolites in tumor cells. J Exp Med 197: 163-168.

24. Cubillos-Ruiz JR, Martinez D, Scarlett UK, et al. (2010): $\mathrm{CD} 277$ is a negative co-stimulatory molecule universally expressed by ovarian cancer microenvironmental cells. Oncotarget 1: 329-338.

25. Chapoval AI, Smithson G, Brunick L, et al. (2013): BTNL8, a butyrophilin-like molecule that costimulates the primary immune response. Mol Immunol 56: 819-828.

26. Le Page C, Ouellet V, Quinn MC, et al. (2008): BTF4/BTN3.2 and GCS as candidate mRNA prognostic markers in epithelial ovarian cancer. Cancer Epidemiol Biomarkers Prev 17: 913920.

27. Le Page C, Marineau A, Bonza PK, et al. (2012): BTN3A2 expression in epithelial ovarian cancer is associated with higher tumor infiltrating $\mathrm{T}$ cell and a better prognosis. PLoS One 7: e38541.

28. Adams EJ, Gu S, Luoma AM (2015): Human gamma delta T cells: evolution and ligand recognition. Cell Immunol 296: 31-40.

29. Marischen L, Wesch D, Schroder JM, et al. (2009): Human $\gamma \delta \mathrm{T}$ cells produce the protease inhibitor and antimicrobial peptide elafin. Scand J Immunol 70: 547-552.

30. Morita CT, Jin C, Sarikonda G, Wang H (2007): Nonpeptide antigens, presentation mechanisms, and immunological memory of human $\mathrm{V} \gamma 2 \mathrm{~V} \delta 2 \mathrm{~T}$ cell: discriminating friend from foe through the recognition of prenyl pyrophosphate antigens. Immunol Rev 215: 59-76.

31. Dieli F, Troye-Blomberg M, Ivanyi J, et al. (2001): Granulysin-dependent killing of intracellular and extracellular Mycobacterium tuberculosis by $\mathrm{V} \gamma 2 \mathrm{~V} \delta 2 \mathrm{~T}$ lymphocytes. J Infect Dis 184: 1082-1085.

32. Dudal S, Turriere C, Bessoles S, et al. (2006): Release of LL37 by activated human $\mathrm{V} \gamma 2 \mathrm{~V} \delta 2 \mathrm{~T}$ cell: a microbial weapon against Brucella suis. J Immunol 177: 5533-5539.

33. Sandstrom A, Peigne CM, Leger A, et al. (2014): The intracellular B30.2 domain of butyrophilin 3A1 binds phosphoantigens to mediate activation of human $\mathrm{V} \gamma 9 \mathrm{~V} \delta 2 \mathrm{~T}$ cell. Immunity 40: 490-500. 
34. Wang H, Morita CT (2015): Sensor function for butyrophilin $3 \mathrm{~A} 1$ in prenyl pyrophosphate stimulation of human $\mathrm{V} \gamma 2 \mathrm{~V} \delta 2$ T cells. J Immunol 195: 4583-4594.

35. Chen ZW (2013): Multifunctional immune response of HMBPP-specific Vgamma2Vdelta2 T cells in M. tuberculosis and other infections. Cell Mol Immunol 10: 58-64.

36. Hintz M, Reichenberg A, Altincicek B, et al. (2001): Identification of (E)-4-hydroxy- 3-methyl-but-2-enyl pyrophosphate as a major activator for human $\gamma \delta \mathrm{T}$ cells in Escherichia coli. FEBS Lett 509: 317-322.

37. Valentonyte R. Hampe J, Huse K, et al. (2005): Sarcoidosis is associated with a truncating splice site mutation in BTNL2. Nat Genet 37: 357-364.

38. Puan KJ, Jin C, Wang H, et al. (2007): Prefernatial recognition of a microbial metabolite by human $\mathrm{V} \gamma 2 \mathrm{~V} \delta 2 \mathrm{~T}$ cell. Int Immunol 19: 657-673.

39. Harly C, Guillame Y, Nedellec S, et al. (2012): Key implication of CD 277/butyrophilin-3 (BTN3A) in cellular stress sensing by a major human gammadelta T-cell subset. Blood 120: 2269-2279.

40. Vavassori S, Kumar A, Wan GS, et al. (2013): Butyrophilin 3A1 binds phosphorylated antigens and stimulates human gammadelta T cells. Nat Immunol 14: 908-916.

41. Rhodes DA, Chen HC, Price AJ (2015): Activation of human gammadelta $\mathrm{T}$ cells by cytosolic interactions of BTN3A1 with soluble phosphoantigens and the cytoskeletal adaptor periplakin. J Immunol 194: 2390-2398.

42. Simone R, Barbarat B, Rabellino A, et al. (2010): Ligation of the BT3 moleucles, members of the B7 family, enhance the proinflammatory responses of the human monocytes and monocyte-derived dendritic cells. Mol Immunol 18: 109-118.

43. Pathan S, Gowdy RE, Cooney R, et al. (2009): Confirmation of the novel association at the BTNL2 locus with ulcerative colitis. Tissue Antigens 74: 322-329.

44. Price P, Santoso L, Mastaglia F, et al. (2004): Two major histocompatibility complex haplotypes influence susceptibility to sporadic inclusion body myositis: critical evaluation of an association with HLA-DR3. Tissue Antigens 64: 575-580.

45. Messal N, Mamessier E, Sylvain A, et al. (2011): Differential role of CD277 as a co-regulator of the immune signal in T and NK cell. Eur J Immunol 41: 3443-3454.

46. Moller M, Kwiatkowski R, Nebel A, et al. (2007): Allelic variation in BTNL2 and susceptibility to tuberculosis in a South African population. Microbes Infect 9: 552-558.

47. Oguri M, Fujimaki T, Horibe H, et al. (2013): Association of a polymorphism of BTN2A1 with chronic kidney disease in community-dwelling individuals. Biomedical Reports 1: 868872.

48. Orozco G, Eerligh P, Sanchez E, et al. (2005): Analysis of a functional BTNL2 polymorphism in type 1 diabetes, rheumatoid arthritis, and systemic lupus erythematosus. Hum Immunol 66: 1235-1241. 